\title{
Enhanced immunogenicity of Renibacterium salmoninarum in chinook salmon after removal of the bacterial cell surface-associated $57 \mathrm{kDa}$ protein
}

\author{
P. A. Wood $^{1}$, S. L. Kaattari ${ }^{2, *}$ \\ ${ }^{1}$ Center for Salmon Disease Research, Department of Microbiology, Oregon State University, Corvallis, Oregon 97331-3804, USA \\ ${ }^{2}$ School of Marine Science, Virginia Institute of Marine Science, College of William and Mary, Gloucester Point, \\ Virginia 23062, USA
}

\begin{abstract}
A study was conducted to determine the effect of endogenous serine protease activity on the immunogenicity of Renibacterium salmoninarum cells in chinook salmon Oncorhynchus tshawytscha. Salmon were immunized with either $R$. salmoninarum cells possessing p57 (p57 ) or substantially depleted of $\mathrm{p} 57$ ( $\mathrm{p} 57^{-}$). The resultant antisera were examined by whole cell ELISA and immunoblot procedures using $\mathrm{p} 57^{+}, \mathrm{p} 57^{-}$, proteinase-K-treated, and periodate-treated whole cells. These analyses revealed that the removal of $\mathrm{p} 57$ by the endogenous serine protease significantly enhanced the immunogenicity of the cell, resulting in a 20 -fold increase in detectable antibody titers. The bulk of this antibody activity was directed at sites blocked by the presence of the p 57 molecule. Furthermore, proteinase-K and periodate treatment of $R$. salmoninarum cells revealed that the increased antibody activity almost exclusively reacted with carbohydrate moieties on the $\mathrm{p}^{-} 7^{-}$cell.
\end{abstract}

KEY WORDS: Renibacterium salmoninarum - Bacterial kidney disease - Humoral immune response Antibodies · Immunogenicity - Whole cell ELISA

\section{INTRODUCTION}

Renibacterium salmoninarum, the causative agent of bacterial kidney disease (BKD) of salmonid fish, is a slow-growing, Gram-positive, obligate intracellular diplobacillus (Young \& Chapman 1978, Fryer \& Sanders 1981, Evenden et al. 1993). Despite advances in the understanding of pathogenicity, immune interactions, and the development of new disease management techniques, BKD continues to plague the culture of salmonids. The ability of the organism to be transmitted both horizontally (Mitchum \& Sherman 1981, Bell et al. 1984) and vertically (Evelyn et al. 1984), to survive and possibly replicate within phagocytic cells, along with its fastidious requirements and slow growth, have made it one of the most difficult fish pathogens to study and control (Evenden et al. 1993, Fryer \& Lannan 1993).

\footnotetext{
-Addressee for correspondence. E-mail: kaattari@vims.edu
}

Currently, there is no vaccine for BKD. Numerous attempts to vaccinate intraperitoneally (IP) with untreated, heat- or formalin-killed whole cells (BaudinLaurencin et al. 1977. Sakai et al. 1989), soluble extracellular proteins (ECP) or crude cell fractions (Evelyn et al. 1984) have failed to reliably protect salmonids (Paterson et al. 1981, McCarthy et al. 1984, Shieh 1989). While untreated whole cells and soluble ECP antigens do not appear to be protective, it is possible other cell-associated antigens may serve as protective antigens in vaccines against BKD.

Despite previous studies aimed at elucidating immune interactions of Renibacterium salmoninarum within the host, only limited information is available concerning the immune response of salmonids to specific antigens of $R$. salmoninarum. Elevated humoral antibody titers have been observed after vaccination with adjuvant and in natural infections (Evelyn 1971 , Weber \& Zwicker 1979, Paterson et al. 1981, Bruno 1987, Sakai et al. 1989). Turaga et al. (1987a) demonstrated by immunoblotting that coho salmon recognize 
R. salmoninarum ECP, which contains p57. Further, chinook salmon recognize p57 and 3 other proteins of unresolved molecular weight (MW) (Bartholomew et al. 1991)

The p57 molecule is well characterized and a focal point of extensive diagnostic, pathogenic and prophylactic studies. This hydrophobic protein possesses hemagglutinating (Daly \& Stevenson 1987) and leukoagglutinating (Wiens \& Kaattari 1991) properties. Also, p57 and other extraceliular products (ECP) are known to suppress plaque-forming cells of salmonid leukocytes in vitro (Turaga et al. 1987a). Rockey et al. (1991) identified an endogenous serine protease that degrades the soluble p57 component of ECP and cell surface-associated p57 at elevated temperatures. In addition, we have demonstrated that heat-induced proteolytic activity causes ECP to lose the ability to suppress the in vitro antibody response.

Based on this information we have reasoned that removal of the immunosuppressive putative virulence factor, p57, may expose new antibody binding sites and enhance the antibody response to other cell surface antigens. We have compared the salmonid humoral immune responses to formalin-killed Renibacterium salmoninarum [which possesses cell-associated p57 $\left.\left(\mathrm{p} 57^{+}\right)\right]$, and heat-treated formalin-killed $R$. salmoninarum [which lacks most of the cell-associated p57 $\left.\left(\mathrm{p} 57^{-}\right)\right]$. Analysis of specific serum antibody titers indicated that removal of p57 from whole cells by heat treatment $\left(37^{\circ} \mathrm{C}\right)$ was critical for enhancing immunogenicity and antigenicity. Further, analysis of $\mathrm{p} 57^{-}$ serum reactivity against heat-treated $\mathrm{p} 57^{-}$cells digested with periodate provided indirect evidence that carbohydrate antigens may also be important immunogens

\section{METHODS}

Animals. Spring chinook salmon Oncorhynchus tshawytscha used in this study were derived from spawned parents that tested negative for BKD by ELISA (Pascho et al. 1991). These fish were obtained from the Dworshak National Fish Hatchery in Ahsahka, Idaho, USA. Three tanks each of 35 fish weighing approximately 20 to $50 \mathrm{~g}$ upon initial injection were maintained in $12^{\circ} \mathrm{C}$, sand-filtered, UV-treated, pathogen-free lake water at the Northwest Biological Science Center of the National Biological Survey in Seattle, WA, USA. Fish were fed Oregon Moist Pellets (OMP) (Bioproducts, Warrington, OR, USA). Coho salmon Oncorhynchus kisutch, weighing 200 to $500 \mathrm{~g}$ upon initial immunization, were maintained at the Salmon Disease Laboratory (SDL) at Oregon State University (OSU), Corvallis, as a source of standard antisera.
Bacterial strains. Renibacterium salmoninarum isolate D-6 (obtained from C. Banner, Oregon Department of Fish and Wildlife, OSU) was cultured on a shaker for 8 to $14 \mathrm{~d}$ to an optical density (OD) of 1.0 $\left(525 \mathrm{~nm}\right.$ ) in kidney disease medium (KDM II) at $17^{\circ} \mathrm{C}$ (Evelyn 1977), excluding calf serum. After centrifugation $\left(6000 \times g, 30 \mathrm{~min}, 4^{\circ} \mathrm{C}\right)$ bacterial pellets were washed $(16000 \times g, 2 \mathrm{~min}) 3$ times with $1 \mathrm{ml}$ cold $10 \mathrm{mM}$ phosphate buffered saline (PBS) $10.85 \% \mathrm{NaCl}$, $10 \mathrm{mM} \mathrm{Na}_{2} \mathrm{PO}_{4}(\mathrm{pH} 7.2)$ ], resuspended to a wet weight concentration of $200 \mathrm{mg} \mathrm{ml}^{-1}$, and stored at $-70^{\circ} \mathrm{C}$. Soluble ECP was harvested from the supernatant as previously described (Turaga et al. 1987a).

Preparation of whole cells. The $p 57^{-}$cells were prepared by incubating $p 57^{+}$cells at $37^{\circ} \mathrm{C}$ for $10 \mathrm{~h}$ Milcrofuged ceil peilets were washed twice in coidd PBS. Both cell preparations were then formaldehydekilled with a $0.3 \%$ solution (EM Science, Cherry Hill, $N J$, USA) in PBS overnight at $4^{\circ} \mathrm{C}$. After washing the cells twice, pellets were resuspended to $200 \mathrm{mg} \mathrm{ml}^{-1}$ in PBS and stored at $-70^{\circ} \mathrm{C}$.

Production of monoclonal antibodies (mAbs). Monoclonal antibodies (mAbs) 4D3, 3H1, and $1 \mathrm{~A} 1$ (Wiens \& Kaattari 1989, 1991) were used to identify p57 and its breakdown products in immunoblots. Ascitic fluid was purified using the caprylic acid procedure of Russo et al. (1983). After precipitation with 50\% ammonium sulfate, the precipitate was resuspended in PBS and extensively dialyzed against PBS, diluted 1:1 in glycerol and stored at $-20^{\circ} \mathrm{C}$.

Antigen preparation and immunization. Chinook salmon were immunized with either $\mathrm{p} 57^{+}$or $\mathrm{p} 57^{-}$whole cell antigens (100 $\mu \mathrm{g}$ bacterial wet weight per fish) emulsified 1:1 in Freund's complete adjuvant (FCA, Sigma, St. Louis, MO, USA) and PBS for 4 min at 100 units on a Virtis '23' mixer (Virtis, Gardiner, NY, USA). A preparation of PBS alone in FCA served as a negative control. Each fish was injected with a total volume of $50 \mathrm{ml}$ intraperitoneally using a $1 \mathrm{cc}$ syringe fitted with a 26/2 gauge needle (Becton Dickinson, Rutherford, NJ). A boost with Freund's incomplete adjuvant (FIA) followed $15 \mathrm{wk}$ after primary immunization at half the concentration in the same total volume.

Collection of antiserum. Individual serum samples were collected from randomly selected fish in the $\mathrm{p} 57^{+}$, p57-, and control groups at 0 and 12 wk post primary immunization and at $17.5 \mathrm{wk}$ post secondary immunization (i.e. $32.5 \mathrm{wk}$ post primary immunization). Blood was taken from the caudal vessel of animals anesthetized in 10\% benzocaine (Sigma). Blood was allowed to clot at room temperature (RT) for several hours. Samples were centrifuged (Beckman model $\mathrm{TJ}-6$ ) at $500 \times g$ for $5 \mathrm{~min}$ at $4^{\circ} \mathrm{C}$, the serum removed, aliquoted and stored at $-70^{\circ} \mathrm{C}$ 
Protein and carbohydrate digestion of whole cells. Aliquots of $80 \mu \mathrm{l}$ of a $\mathrm{p} 57^{+}$or $\mathrm{p} 57^{-}$cell stock $10 \mathrm{mg}$ $\mathrm{ml}^{-1}$ ) were treated with $20 \mu \mathrm{l}$ of $0.2 \mathrm{M}$ meta-periodate (Sigma) in dd $-\mathrm{H}_{2} \mathrm{O}$, or with $20 \mu \mathrm{l}$ PBS (control). Cells were incubated at $4^{\circ} \mathrm{C}$ for $24 \mathrm{~h}$ as described by Liang et al. (1992). The same cell concentration was used for the proteinase-K treatment (1 $\mathrm{mg} \mathrm{ml}^{-1}$ ) (Sigma) in $0.1 \mathrm{M}$ tris $\mathrm{HCl}, \mathrm{pH}$ 8.0. Cells were incubated in the dark at RT for $24 \mathrm{~h}$ (Mack et al. 1992). Periodate and proteinase were removed by washing the cells twice in PBS, and by resuspending the cells in the original buffer.

Determination of antibody activity by ELISA. In preparing the coating antigen for the enzyme-linked immunosorbent assay (ELISA), it was anticipated that different treatments might alter the cell's plastic binding capacities. Therefore, it was necessary to determine the plate coating efficiency of each $R$. salmoninarum preparation (i.e. untreated, heat-, proteinase-, and periodate-treated). Upon determination of this property, the appropriate coating antigen concentration was applied to the ELISA plate wells to yield a comparable number of bound bacteria per well. We chose concentrations of cells which would bind $50 \%$ of the ELISA well surface (Fig. 1). To accomplish this, the peroxidase saturation technique of Munoz et al. (1986) was applied with minor modifications. Briefly, dilutions of whole cells were incubated in wells

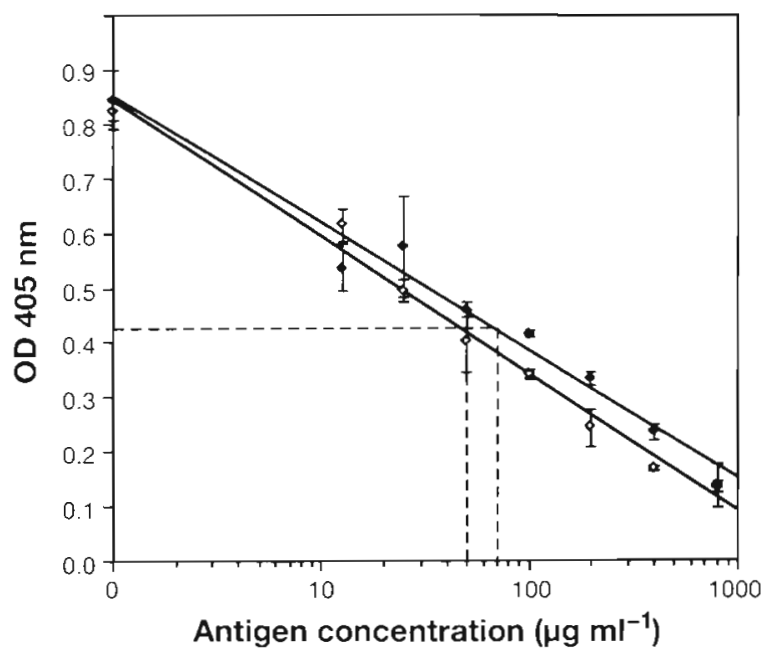

Fig. 1. Determination of whole cell antigen concentration needed to occupy $50 \%$ of the surface of an ELISA plate well. Plates were coated with graded concentrations of each antigen, and antigen adsorption in the well was determined using horseradish peroxidase to determine percentage of non-occupied surface sites (Munoz et al 1986). Logarithmic curve-fit interpolation was calculated, and surface antigen concentration to be employed was calculated as that corresponding to the intersection of the $50 \%$ saturation line. Results corresponding to $p 57^{+}$whole cell antigens $(0)$ and p57- whole cell antigens $(\bullet)$ are plotted together. Error bars represent $2 \mathrm{SD}$ about the mean overnight at $17^{\circ} \mathrm{C}$. The $R$. salmoninarum suspensions were then removed and replaced with a saturating concentration ( $1 \mathrm{mg} \mathrm{ml}^{-1}$ ) of horseradish peroxidase (HRPO). The peroxidase solution was incubated for $1 \mathrm{~h}$ at RT. Plates were washed 10 times with a $0.1 \%$ Tween 20 in tris-buffered saline (TTBS; $50 \mathrm{mM}$ tris, 1 mM EDTA, 8.7\% NaCl, pH 8.0) with a Titertek Automatic Microplate Washer (Flow Laboratories, McLean, VA, USA) and blocked with $200 \mu \mathrm{l}$ well ${ }^{-1}$ of $1 \%$ bovine serum albumin (BSA; Fraction V, Sigma) in TTBS for $1 \mathrm{~h}$ at RT. Substrate $\left(\mathrm{H}_{2} \mathrm{O}_{2}\right)$ and $3^{\prime}, 2^{\prime}$ azino-bis (ethyl)benzthiaoline sulfonic acid (ABTS) solutions were then added as per the original protocol (Arkoosh \& Kaattari 1990)

The concentration of antibody activity was determined by the use of a modification of the ELISA as described by Arkoosh \& Kaattari (1990). Formalinfixed $\mathrm{p} 57^{+}\left(50 \mu \mathrm{g} \mathrm{ml^{-1 } )}\right.$ or p57- cells $\left(70 \mu \mathrm{g} \mathrm{m}^{-1}\right)$ were coated on E.I.A./R.I.A. ELISA plates (Costar, Cambridge, MA, USA) overnight at $17^{\circ} \mathrm{C}$. Plates were then blocked with $1 \%$ BSA-TTBS for 1 h at RT and washed 5 times in TTBS. Each plate containing 5 dilutions of each test serum and the standard were incubated for 90 min at RT.

A standard antiserum was derived by pooling salmon sera to whole Renibacterium salmoninarum. This pool was made sufficiently large so that enough standard serum would be available for the completion of all experiments within this study. The titer of the standard reflected the dilution of the standard required to achieve $50 \%$ of the maximum OD. Plates were washed 10 times after each step of the assay. The presence of anti- $R$. salmoninarum antibody in the serum samples was detected using a biotinylated mouse anti-trout immunoglobulin monoclonal antibody, 1-14 (DeLuca et al. 1983), diluted 1:1500 in 1\% BSA-TTBS. After washing, streptavidin-conjugated HRPO (Sigma) diluted 1:200 in 1\% BSA-TTBS was added and incubated $45 \mathrm{~min}$. After washing, substrate $\left(\mathrm{H}_{2} \mathrm{O}_{2}\right)$ and ABTS were added. Plates were read kinetically for $10 \mathrm{~min}$ at $405 \mathrm{~nm}$ with a Titertek Multiskan Automatic Reader (Flow Laboratories). The initial reaction rates were then calculated

Titers were determined by first calculating the volume of each serum required to achieve $50 \%$ of the maximum OD rate (Arkoosh \& Kaattari 1990). This value was then transformed into a titer (units of antibody activity $\mu^{-1}$ ) using the following equation:

\footnotetext{
$\frac{\text { Volume of standard-MAX }}{\text { Volume of test-MAX }} \times 10000 \mathrm{U}_{50} \mathrm{l}^{-1}$ (Titer of standard)
}

Direct comparison of the $50 \%$ point with the standard serum allowed normalization of data values from all sera and reduced plate-to-plate variation. Sample titrations are depicted (Fig. 2). 


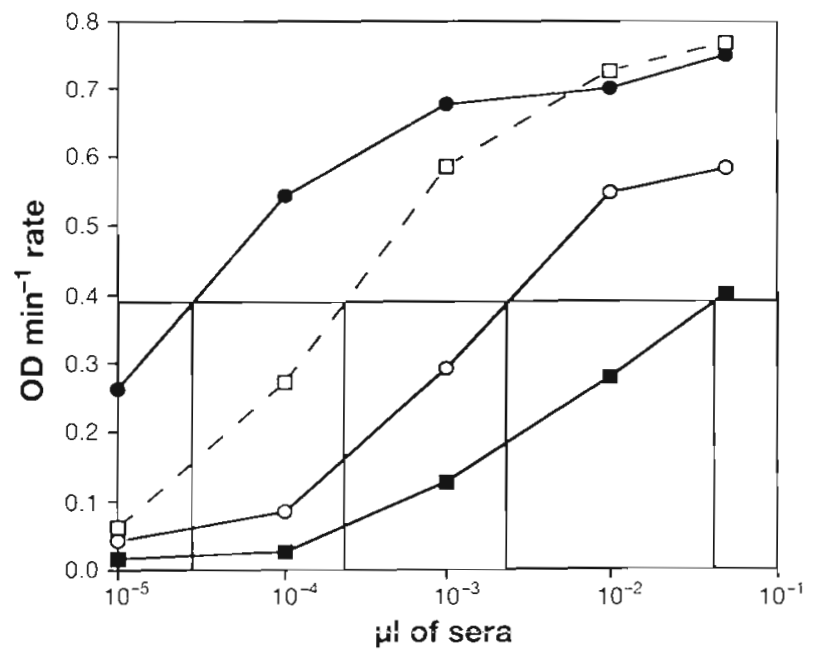

Fig. 2. Determination of serum antibody activity from 3 samples. Data were expressed as initial reaction rate (OD $\mathrm{min}^{-1}$ ). Amount of antibody activity was calculated as described in the text using the method described by Arkoosh \& Kaattari (1990). In this example the standard (ㅁ) was assigned a

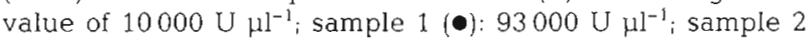
(0): $1.000 \mathrm{U} \mathrm{\mu l}^{-1}$; sample $3(\mathbb{\square}): 80 \mathrm{U} \mathrm{\mu l}^{-1}$

Preparation of whole cells for SDS-PAGE and immunoblotting. Whole cells (20 $\left.\mathrm{mg} \mathrm{m}^{-1}\right)$ were mixed $1: 1$ in sample application buffer (SAB) $(120 \mathrm{mM}$ tris, $4 \%$ SDS, $10 \%$ 2-mercaptoethanol, $20 \%$ glycerol, and $3 \mathrm{mM}$ bromophenol blue) or $5 \mu \mathrm{l}\left(100 \mathrm{mg} \mathrm{ml}^{-1}\right)$ of cells were mixed with $120 \mu \mathrm{ldd}-\mathrm{H}_{2} \mathrm{O}$ and $125 \mu \mathrm{l}$ of $\mathrm{SAB}$ and boiled for 3 min. Resulting boiled extracts were then electrophoresed in 10\% SDS-polyacrylamide gels (SDS-PAGE) in a Mini-protean II electrophoresis apparatus (Bio-Rad, Richmond, CA, USA) at $200 \mathrm{~V}$ for $1 \mathrm{~h}$. Gels were equilibrated in transfer buffer $(192 \mathrm{mM}$ glycine, $20 \mathrm{mM}$ tris, pH 8.3, 20\% methanol), and the proteins were electrophoretically transferred to immobilon-P (Millipore, Bedford, MA) at $100 \mathrm{~V}$ for $1 \mathrm{~h}$ at $4^{\circ} \mathrm{C}$.

Immunoblotting was performed after blocking the membranes with $1 \%$ BSA-TTBS for $1 \mathrm{~h}$ at RT or overnight at $4^{\circ} \mathrm{C}$. Blots were washed 3 times for $10 \mathrm{~min}$ in TTBS, rinsed in dd $-\mathrm{H}_{2} \mathrm{O}$, and inserted into a Miniblotter apparatus (Immunetics, Cambridge, MA). Individual salmon serum samples (70 U $70 \mu \mathrm{l}^{-1}$ ) and positive control mAbs 4D3, 3H1, and $1 \mathrm{~A} 1\left(3 \mu \mathrm{g} \mathrm{m} \mathrm{m}^{-1}\right)$ in $1 \% \mathrm{BSA}-$ TTBS were each added to each well of the apparatus and incubated for 1.5 to $2 \mathrm{~h}$ at RT with gentle shaking. After rinsing wells 3 times with TTBS, blots were removed and rinsed with TTBS 3 times for $10 \mathrm{~min}$. After washing, blots were incubated for $1 \mathrm{~h}$ in 1-14 $\left(5 \mu \mathrm{g} \mathrm{m} l^{-1}\right)$ in $1 \%$ BSA-TTBS and washed. They were then incubated with peroxidase-conjugated goat antimouse-Ig (Hyclone, Logan, UT, USA) diluted 1:5000 in $1 \%$ BSA-TTBS for 45 min at RT.
Densitometry. SDS-PAGE and electrotransfer of p5 $7^{-}$or $p 57^{+}$extracts and molecular weight markers were performed as described above. The membranes were then stained for total protein with colloidal gold solution (Bio-Rad) using a procedure provided by the manufacturer. Blots were washed extensively, dried, and the total protein stained blots were scanned with a helium neon laser beam, Personal Densitometer SI, model PDSI-PC, and Image Quant data recorder (Molecular Dynamics, Sunnyvale, CA).

Statistical analysis. Antibody titers were log-transformed and analyzed using a Student $t$-test program on the Statgraphics software package to determine significance of each group of mean sera sample values tested in an ELISA against both $\mathrm{p} 57^{+}$and $\mathrm{p} 57^{-}$cells. The reported vaiues in units of antibody activity per $\mu \mathrm{i}$ of serum ( $\mathrm{U} \mathrm{Hl}^{-1}$ ) were back transformed. P-values exceeding 0.05 were not considered significant.

\section{RESULTS}

\section{Quantitative and qualitative analysis of $\mathrm{p} 57^{+}$and $\mathrm{p} 57^{-}$ Renibacterium salmoninarum cells}

To visualize the effects of $10 \mathrm{~h}$ of heat treatment on Renibacterium salmoninarum surface proteins, $\mathrm{p} 57^{+}$ and $557^{-}$cell extracts were electrophoresed and stained for total protein (Fig. 3). There was a substantial reduction in the amount of the p57 molecule present and concomitantly there was an increase in the

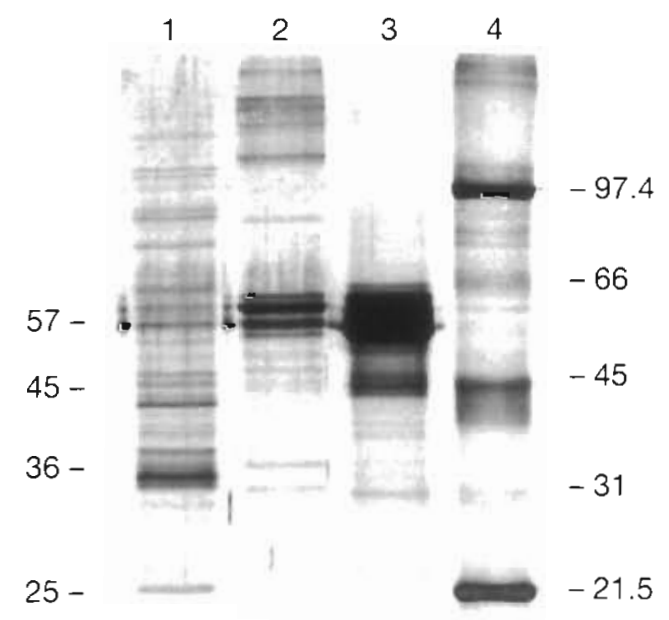

Fig. 3. Renibacterium salmoninarum. Analysis of $\mathrm{p} 57$ reduction on the cell surface by $10 \%$ SDS-PAGE and total protein staining. Total protein stain of $50 \mu \mathrm{g}$ of $R$. salmoninarum ECP, whole cells $\left(\mathrm{p} 57^{+}\right)$, and whole cells heat-treated at $37^{\circ} \mathrm{C}$ for $10 \mathrm{~h}\left(\mathrm{p} 57^{-}\right)$. Lanes: 1, formalin-killed p57- cells; 2 , formalinkilled $\mathrm{p} 57^{+}$cells; $3, \mathrm{ECP} ; 4$, molecular weight standards in kilodaltons 
p36 and other lower molecular weight breakdown products. Fig. 4 illustrates the densitometric profiles of each cell type before and after heat treatment. These profiles indicate that p57 comprised approximately $70 \%$ of all protein on $57^{+}$cells and that only $14 \%$ of the p57 molecule remained after heat treatment.

\section{Determination of antibody activity to $\mathrm{p} 57^{+}$and $\mathrm{p} 57^{-}$ Renibacterium salmoninarum}

The range of antibody titers present in individual salmon sera at $12 \mathrm{wk}$ post primary injection varied

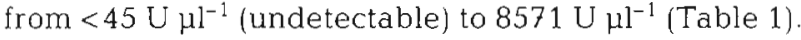
The mean titer against $\mathrm{p} 57^{-}$cells from fish immunized with $\mathrm{p} 57^{-}$cells was approximately 5 -fold higher than the mean titer from fish immunized with $\mathrm{p} 57^{+}$cells. Sera from adjuvant injected fish (controls) had non-
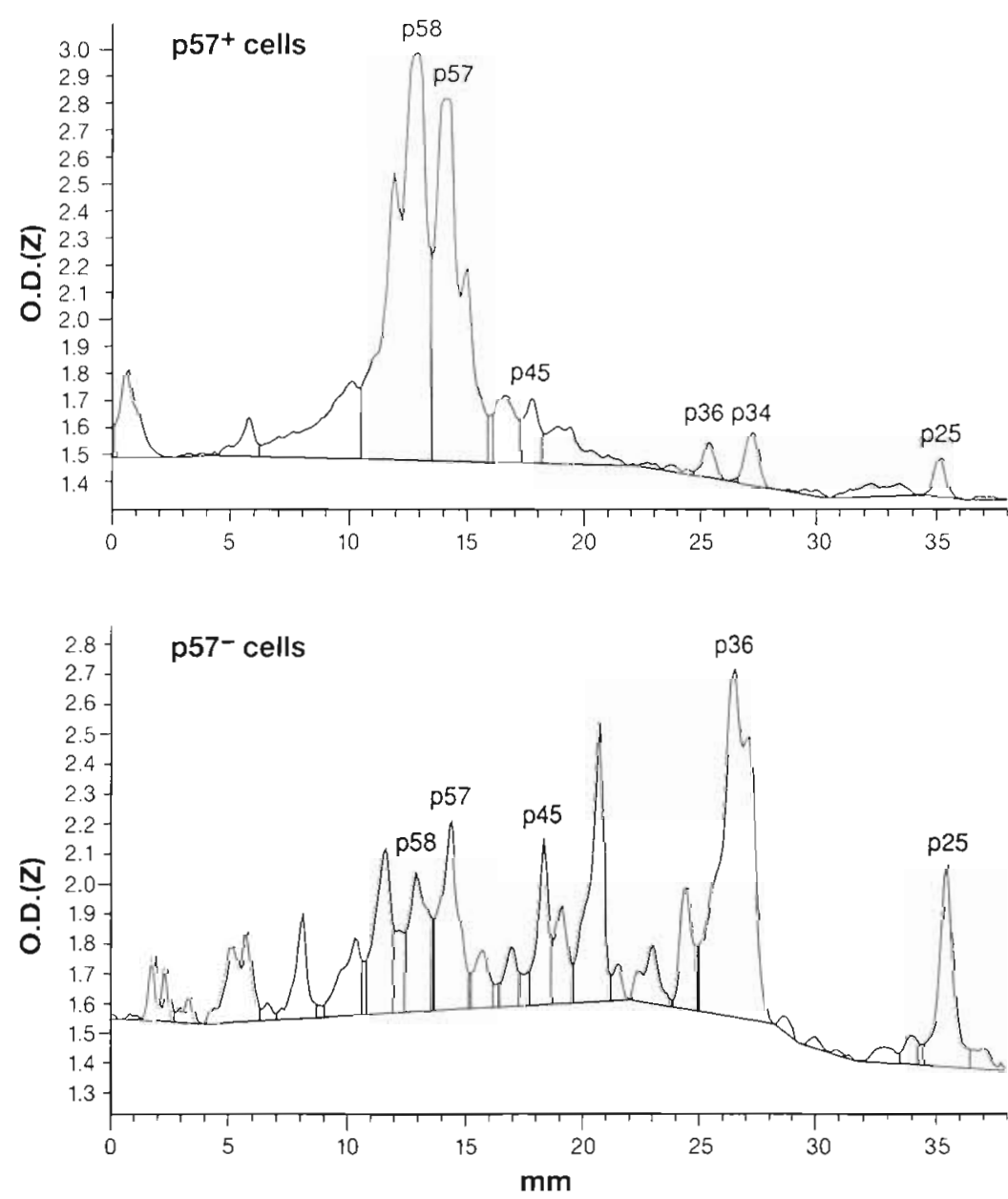

Fig. 4. Renibacterium salmoninarum. Densitometer scan of a total protein stained blot of $p 57^{+}$and $p 57^{-}$cells as detected by colloidal gold staining. Peaks are labeled with proteolytic breakdown products corresponding to their molecular weight in kilodaltons. The $y$-axis is labeled in intensity units signifying signal strength. The $x$-axis represents the distance scanned in millimeters detectable titers. At 17.5 wk post secondary injection,

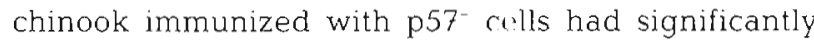
higher antibody titers ( $p \leq 0.01$; Table 2 ) than fish immunized with native $p 57^{+}$cells, when reacted with

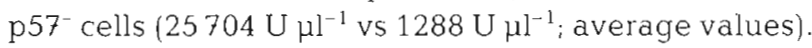
The mean titers of $\mathrm{p} 57^{+}$and $\mathrm{p} 57^{-}$immune sera were comparable when assessed against $p 57^{+}$cells. All control fish demonstrated non-detectable titers, as did prebleeds from all the immunized fish.

\section{Detection of primary immunogenic surface proteins on $\mathrm{p}^{+}$and $\mathrm{p57}^{-}$Renibacterium salmoninarum whole cells by immunoblotting}

Blots of extracts from p57 $7^{+}$(Fig. 5A) or p57- cells (Fig. 5B) were probed with $17.5 \mathrm{wk}$, post secondary sera from 10 individual chinook immunized with p $57^{+}$cells and 5 chinook immunized with $\mathrm{p} 57^{-}$heat-treated cells to attempt identification of any differences in the proteins recognized on untreated, treated, and heat-treated cells. The only cell-associated proteins recognized by either $\mathrm{p} 57^{+}$or $\mathrm{p} 57^{-}$salmon antibodies were p57 and its breakdown products (ECP). Most of the antibody response to $\mathrm{p} 57^{+}$cells was directed against $\mathrm{p} 57$, while serum antibodies reacted predominantly with p36 on $157^{-}$cells. Recognition patterns of the mAbs are representative of those that react with an amino terminal epitope (group I: mAb 4D3), an internal epitope (group II: mAb $3 \mathrm{H} 1$ ), or a carboxy-terminal epitope (group III: $\mathrm{mAb}$ 1A1) of the p57 molecule, as described by Wiens \& Kaattari (1991).

\section{Determination of $\mathrm{p} 57^{-}$antisera specificity by protein and carbo- hydrate disruption of $\mathrm{p} 57^{+}$and p57 $7^{-}$cells}

To determine the extent of antibody recognition of protein versus carbohydrate components in the high-titered $\mathrm{p} 57^{-}$antisera, the surface protein of $\mathrm{p} 57^{+}$and $\mathrm{p} 57^{-}$cells was digested by proteinase- $K$ or the surface carbohydrate degraded by periodate prior to reaction with serum from p57 $7^{-}$immunized fish (Table 3). Comparable coating concentrations of each digested 
Table 1 . Serum antibody titers from chinook salmon immunized with p $57^{+}$or p57- Renibacterium salmoninarum whole cells at 12 wk post primary injection Each serum was tested on each cell preparation. Control fish were injected with PBS in adjuvant. Values denote non-detectable titers

\begin{tabular}{|c|c|c|c|c|c|c|c|c|}
\hline \multicolumn{9}{|c|}{ Antıbody activity as measured by ELISA (units $\mu \mathrm{l}^{-1}$ ) } \\
\hline \multicolumn{3}{|c|}{ p57+sera } & \multicolumn{3}{|c|}{$\mathrm{p} 57^{-}$sera } & \multicolumn{3}{|c|}{ Control sera } \\
\hline Fish & $\begin{array}{l}\text { p5 } \\
\text { cells }\end{array}$ & $\begin{array}{l}\text { p } 57^{+} \\
\text {cells }\end{array}$ & $\begin{array}{l}\text { Fish } \\
\text { cells }\end{array}$ & $\begin{array}{l}\text { p57 } \\
\text { cells }\end{array}$ & $\begin{array}{l}\text { p } 57^{+} \\
\text {cells }\end{array}$ & $\begin{array}{l}\text { Fish } \\
\text { cells }\end{array}$ & $\mathrm{p} 57^{-}$ & $\mathrm{p} 57^{+}$ \\
\hline 1 & 90 & 58 & 6 & 857 & 55 & 11 & $<70$ & $<45$ \\
\hline 2 & 300 & 58 & 7 & 75 & 55 & 12 & $<70$ & $<45$ \\
\hline 3 & 90 & 58 & 8 & 987 & 55 & 13 & $<70$ & $<45$ \\
\hline 4 & 300 & 144 & 9 & 750 & $<45$ & 14 & $<70$ & $<45$ \\
\hline 5 & 225 & 88 & 10 & 8571 & $<45$ & 15 & $<70$ & $<45$ \\
\hline $\begin{array}{l}\text { Mea } \\
\text { titer }\end{array}$ & 174 & 83 & $832^{\circ}$ & 51 & $<70$ & $<45$ & & \\
\hline
\end{tabular}

Table 2. Serum antibody titers from chinook salmon immunized with $\mathrm{p} 57^{+}$or p57- Renibacterium salmoninarum whole cells at 17.5 wk post secondary injection. Fish were boosted $15 \mathrm{wk}$ post primary injection as described in 'Methods' Control fish were injected with PBS in adjuvant. Values denote non-detectable titers. NE: not enough serum available to perform the assay

\begin{tabular}{|c|c|c|c|c|c|c|c|c|}
\hline \multicolumn{9}{|c|}{ Antibody activity as measured by ELISA (units $\mu^{-1}$ ) } \\
\hline \multicolumn{3}{|c|}{ p5 $7^{+}$sera } & \multicolumn{3}{|c|}{ p5 $57^{-}$sera } & \multicolumn{3}{|c|}{ Control sera } \\
\hline Fish & $\begin{array}{l}\mathrm{p} 57^{-} \\
\text {cells }\end{array}$ & $\begin{array}{l}\text { p5 } 57^{+} \\
\text {cells }\end{array}$ & Fish & $\begin{array}{l}\text { p57- } \\
\text { cells }\end{array}$ & $\begin{array}{l}\text { p5 } 57^{+} \\
\text {cells }\end{array}$ & Fish & $\begin{array}{l}\mathrm{p} 57^{-} \\
\text {cells }\end{array}$ & $\begin{array}{l}\text { p5 } 57^{+} \\
\text {cells }\end{array}$ \\
\hline 20 & 122580 & 93000 & 30 & 70707 & 136 & 40 & $<70$ & $<45$ \\
\hline 21 & 1520 & 1000 & 31 & 1077 & 95 & 41 & $<70$ & $<45$ \\
\hline 22 & 95 & 80 & 32 & 77778 & 12667 & 42 & $<70$ & $<45$ \\
\hline 23 & 10556 & 3500 & 33 & 8750 & 475 & 43 & $<70$ & $<45$ \\
\hline 24 & 1.056 & 1000 & 34 & 73684 & 1357 & 44 & $<70$ & $<45$ \\
\hline 25 & 1650 & 987 & 35 & 1280 & 88 & 45 & $<70$ & $<45$ \\
\hline 26 & 138 & 113 & 36 & 145450 & 6563 & 46 & $<70$ & $<45$ \\
\hline 27 & 206 & 75 & 37 & 8889 & 636 & 47 & $<70$ & $<45$ \\
\hline 28 & 917 & 5807 & 38 & $\mathrm{NE}$ & $N E$ & 48 & $<70$ & $<45$ \\
\hline 29 & 1375 & 487 & 39 & 800000 & 65625 & 49 & $<70$ & $<45$ \\
\hline $\begin{array}{l}\text { Mea } \\
\text { titer }\end{array}$ & a 1288 & 955 & & $25704^{*}$ & 1096 & & $<70$ & $<45$ \\
\hline
\end{tabular}

cell type (using the peroxidase saturation technique) revealed that an average of only $4 \%\left(10000 \mathrm{U} \mathrm{\mu l}^{-1}\right)$ of p $57^{-}$reactivity remained after carbohydrate disruption. However, $85 \%\left(212000 \mathrm{U} \mathrm{ul}^{-1}\right)$ of the reactivity remained after protein digestion. Further, periodate treatment of $\mathrm{p} 57^{+}$cells slightly enhanced the reactivity of the $\mathrm{p} 57^{-}$serum to $\mathrm{p} 57^{+}$cells. However, titers to untreated $\mathrm{p} 57^{+}$cells were approximately 180 -fold lower

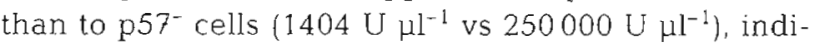
cating that this latter apparent increase was relatively marginal.

\section{DISCUSSION}

The nature of Renibacterium salmoninarum antigens and their relative immunogenicity in salmonids remains largely uncharacterized. This study utilized a novel method for removing a majority of the immunosuppressive, putative virulence factor, p57, from the surface of whole cells by heatinduction $\left(37^{\circ} \mathrm{C}\right)$ of an endogenous serine protease (Rockey et al. 1991). The removal of p57 was associated with increased antigenicity and immunogenicity. Analysis by ELISA of salmon antiserum to $\mathrm{p} 57^{-}$R. salmoninarum revealed a significantly elevated (20fold) specific antibody response.

A similar phenomenon has been observed upon immunization of carp with heat-killed Aeromonas hydrophila cells. This preparation induced a higher agglutinating antibody titer over a period of $32 \mathrm{wk}$ than did formalin-killed cells (Lamers \& Van Muiswinkel 1986). The authors speculated that heating may release more antigenic material without altering antigen structure or proper antigen processing by macrophages.

In an attempt to identify the nature of the antigens remaining on the $\mathrm{p} 57^{-}$cell, immunoblot analysis was performed with $\mathrm{p} 57^{+}$and $\mathrm{p} 57^{-}$antisera against $\mathrm{p} 57^{+}$and $\mathrm{p} 57^{-}$cells. Only 3 or 4 proteins were detected on either cell type by the salmon antisera, namely the p57 molecule and its proteolytic breakdown products. The identification of no new antigenic species suggests that the immunoblot method may not be able to capture these putative antigens. Wethered et al. (1988) examined human sera reactions to fungal proteins also by immunoblot procedures and found that they could only visualize a few proteins, even though the antibody titers were quite high. These authors suggested that the antibody response may be directed against carbohydrate antigens which are not detectable on an immunoblot. Such an explanation may apply to our immunoblot results. In fact, it can be seen that some individual sera demonstrated little or no reactivity when immunoblotted, even though the same concentration of antibody

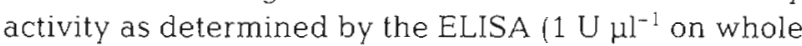
cells) was used for each serum. This indicates that other 


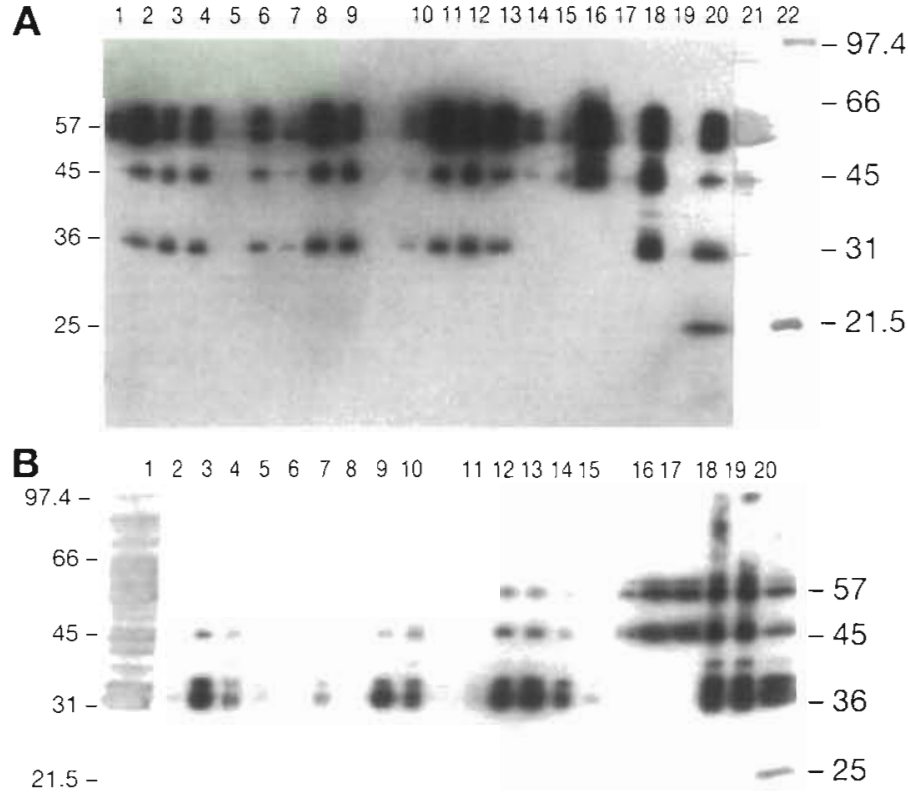

Fig. 5. Renibacterium salmoninarum. Immunoblot analysis with anti$\mathrm{p} 57^{+}$and $\mathrm{p} 57^{-}$immune chinook serum at 17.5 weeks post secondary immunization. (A) $\mathrm{p} 57^{+}$whole cells or (B) $\mathrm{p} 57^{-}$whole cells were probed with serum against $\mathrm{p} 57^{+}$cells and $\mathrm{p} 57^{-}$cells from individual fish, and 3 different anti-p $57 \mathrm{mAb}$ controls. Anti $\mathrm{p} 57^{+}$sera: lanes A1 to 9 and $B 2$ to 10 ; anti $\mathrm{p}^{-7^{-}}$sera: lanes $\mathrm{A} 10$ to 14 and $\mathrm{B} 11$ to $15 ; \mathrm{mAb}$ 4D3: lanes $\mathrm{A} 16$ and $\mathrm{B} 16,17 ; \mathrm{mAb} 3 \mathrm{H} 1$ lanes $\mathrm{A} 18$ and $\mathrm{B} 18,19 ; \mathrm{mAb}$ $1 A 1$. lanes $A 20$ and $B 20$. Total protein stain of $p 57^{+}$whole cells: lane A21; total protein stain of p57 whole cells: lane B1; molecular weight markers: A22

antigens were present on the intact cell that could not be detected on the immunoblots. Also, recognition shifted in $\mathrm{p} 57^{-}$-immunized fish from $\mathrm{p} 57$ to $\mathrm{p} 36$. This correlates with the decrease in $p 57$ and the increase in p36 after treatment at $37^{\circ} \mathrm{C}$ as demonstrated by total protein staining (Fig. 3) and densitometry (Fig. 4).

Table 3. Renibacterium salmoninarum. Effects of enzymatic and chemical treatment of cells on anti-p57 reactivity. Antibody titers were determined as described in 'Method's' Values represent the average antibody titers (units $\mu l^{-1}$ ) of antisera derived from 2 salmon immunized with $p 57^{-}$cells and bled $17.5 \mathrm{wk}$ post secondary immunization. Untreated, pro-

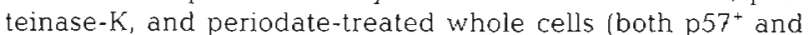
$\mathrm{p} 57^{-}$) were coated onto ELISA wells. Concentrations of each treated cell type were adjusted to ensure that there were equivalent amounts of bound cells in each well

\begin{tabular}{|lcc|} 
& p57 cells & $\mathrm{p} 57^{+}$cells \\
\hline Untreated & 250000 & 1404 \\
Proteinase-K & 212000 & 1123 \\
Periodate & 10000 & 6037 \\
\hline
\end{tabular}

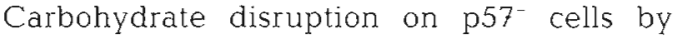
periodate resulted in a reduced ability of the cells to react with the p57- sera (Table 3 ). Although cell-associated proteins did elicit an antibody response, periodate sensitive moieties, probably carbohydrate components, were responsible for most of the elevated serum antibody reactivity to $\mathrm{p} 57^{-}$cells. These results suggest the importance of Renibacterium salmoninarum carbohydrates (possibly polysaccharides) as immunogens and antigens

It is not known why the reactivity of the relatively low-titered anti-p $57^{+}$sera increased after periodate treatment of Renibacterium salmoninarum. Perhaps, in situations where the anticarbohydrate response is blocked, most of the antibodies are directed towards non-periodate or proteinase K-sensitive determinants, such as p57.

One explanation for the observed phenomena would be that p57 acts to occlude the interaction of antibodies or antigen receptors with immunogenic surface molecules. In this case, proteolytic modification by an endogenous serine protease may increase exposure of immunogenic carbohydrate epitopes masked by $\mathrm{p} 57$. There are reports of occlusion by different components of bacterial species, which include blocking of antigens by $S$ layer proteins, concealment of cell wall and $O$ antigens by capsular polysaccharide (King \& Wilkison 1981, Kadurugamuwa et al. 1985, Williams et al. 1986, Johne et al. 1989), and shielding by the LPS O antigen (Mutharia \& Hancock 1983, Jessop \& Lambert 1985, Pollack et al. 1989) and outer core (Gigliotti \& Shenep 1985, Nelson et al. 1990).

Dooley et al. (1985) report masking of the LPS core oligosaccharide-polysaccharide linkage by the $\mathrm{S}$ layer protein in the fish pathogen Aeromonas hydrophila. Sulfo-NHS-biotin cell surface labeling has been used to demonstrate occlusion of outer membrane (OM) antigens by the $52 \mathrm{kDa}$ major surface array protein or $\mathrm{S}$ layer in $A$. hydrophila. The restricted access of this compound as shown by immunoblotting, demonstrated that the OM proteins from selected strains of $A$. hydrophila are shielded from immune recognition (Dooley \& Trust 1988).

There are many ways in which a physical barrier on a bacterial surface may be disrupted, thereby unmasking surface antigens. Chemical degradation is known to partially remove $O$ antigens on rough mutants, unmasking bacterial surface sites (Luderizt et al. 1966). There is also documentation that heat treatment $\left(55^{\circ} \mathrm{C}\right)$ of Gram-negative bacterial cells destroys the integrity of the OM allowing better penetration of antibodies for reaction with core epitopes in O-polysaccharide 
mutants (Tsuchido et al. 1985). Further, removal of the Escherichia coli $\mathrm{K}$ antigen by heating or by enzyme treatment unmasks $\mathrm{O}$ antigens allowing agglutination by anti-O serum (Orskov et al. 1963, Stirm et al. 1971). In addition, heating is known to increase antibody binding to whole bacteria (Nelson et al. 1991).

Other effective abrogating mechanisms of specific humoral immunity are processes that prevent antibody synthesis. The soluble ECP of Renibacterium salmoninarum has been shown to inhibit antibody production in coho salmon B cells in vitro (Turaga et al, 1987b). In addition, heating purified extracellular and cellassociated ECP, which resulted in the degradation of p57 and other immunoreactive ECP components, caused a reduction of its immunosuppressive function (Rockey et ai. 1991). Perhaps in this study, we are seeing the same effect as indicated by the increase in antibody production after p57 degradation by a proteolytic enzyme. In this study, perhaps p57 was inactivated after cleavage by the heat-activated serine protease.

Bacterial components from a number of mammalian and fish pathogens have been demonstrated to alter immune responsiveness of the animal host. Extracellular products of oral bacteria have been known to inhibit lymphacyte mitogenesis (Higerd et al. 1978). Hastings \& Ellis (1988) speculated that the poor immunogenicity of the formalin-activated ECP protease of Aeromonas salmonicida in trout may be due to suppression of the antibody-producing system by the protease

In conclusion, we have shown that there is an enhanced antibody response following modification of the whole bacterial cell using a novel approach. We reasoned that elimination of virulence factors from the bacterial immunogen might enhance immunogenicity. The elimination of the virulence factors was achieved by inducing endogenous proteolytic activity. The removal of the virulence factors significantly increased the magnitude of the antibody response to the injected whole cell antigen and enhanced its antigenicity (ability to react with antibody) as judged by the immunoassay results. Our findings are most consistent with the possibility that 557 may be occluding crucial immunogenic carbohydrate antigens.

Acknowledgements. P.A.W. was supported in part by the U.S. Army Corps of Engineers Walla Walla District under contract number JTF-92-XX-3. The research was supported by USDA (WRAC) no. 91-38500-6078 and the U.S. Department of the Interior under contract number MON-OAS-92-556. We thank R. Pascho for bleeding fish from the U.S. Fish and Wildlife Service facilities in Seattle, C. Banner for Renibacterium salmoninarum strain D-6, and Dr M. Adkison for assistance with optimizing immunoblotting conditions and mAb purification. We also thank Dr G. Wiens for critical editorial advice. This is Oregon Agricultural Experiment Station Technical Paper Number 10646.

\section{LITERATURE CITED}

Arkoosh MR, Kaattari SL (1990) Quantitation of fish antibody to a specific antigen by an enzyme-linked immunosorbent assay (ELISA). In: Stolen JS, Fletcher TC, Anderson DP, Roberson BS, Van Muiswinkel WB (eds) Techniques in fish immunology, Vol 3. SOS Publications, Fair Haven, NJ, p 15-24

Bartholomew JL, Arkoosh MR, Rohovec JS (1991) Demonstration of the specificity of the salmonid humoral response to Renibacterium salmoninarum with a monoclonal antibody against salmonid immunoglobulin. J Aquat Anim Health 3:254- -259

Baudin-Laurencin F, Vigneulle M, Mevel M (1977) Premieres observations sur la corynebacteriose des salmonides en Bretagne. Bull Off Int Epiz 87:505-507

Bell GR, Higgs DA, Traxler GS (1984) The effect of dietary ascorbate, zinc and manganese on the development of experinentally induced bacterial kidney disease in sockeye salmon (Oncorhynchus nerka). Aquaculture 36 : $291-311$

Bruno DW (1987) Serum agglutinating titers against Renibacterium salmoninarum the causative agent of bacterial kidney disease, in rainbow trout, Salmo gairdneri Richardson, and Atlantic salmon, Salmo salar L. J Fish Biol 30:327-334

Daly JG, Stevenson RM (1987) Hydrophobic and haemagglutinating properties of Renibacterium salmoninarum. J Gen Microbiol 133:3575-3580

DeLuca D, Wilson M, Warr GW (1983) Lymphocyte heterogeneity in the trout (Salmo gairdneri), defined with monoclonal antibodies to IgM. Eur J Immunol 13:546-551

Dooley JSG, Lallier R, Shaw DH. Trust TJ (1985) Electrophoretic and immunochemical analysis of the lipopolysaccharides from various strains of Aeromonas hydrophila. J Bacteriol 164:263-269

Dooley JSG, Trust TJ (1988) Surface protein composition of Aeromonas hydrophila strains virulent for fish: identification of a surface array protein. J Bacteriol 170:499-506

Evelyn TPT (1971) The agglutinin response in sockeye salmon vaccinated intraperitoneally with a heat-killed preparation of the bacterium responsible for salmon kidney disease. J Wild Dis 7:328-335

Evelyn TPT (1977) An improved growth medium for the kidney disease bacterium and some notes on using the medium. Bull Off Int Epiz 87:511-513

Evelyn TPT, Ketcheson JE, Prosperi-Porta L (1984.) Further evidence for the presence of Renibacterium salmoninarum in salmonid eggs, and for the failure of povidone-iodine to reduce the intra-ovum infection rate in water-hardened eggs. J Fish Dis 7:173-182

Evenden AJ, Grayson TH, Gilpin ML, Munn CB (1993) Renibacterium salmoninarum and bacterial kidney disease - the unfinished jigsaw. A Rev Fish Dis 3:87-1.04

Fryer JL, Lannan CN (1993) The history and current status of Renibacterium salmoninarum, the causative agent of bacterial kidney disease in Pacific salmon. Fish Res 17:15-33

Fryer JL, Sanders JE (1981) Bacterial kidney disease of salmonid fish. A Rev Microbiol 35:273-298

Gigliotti F, Shenep JL (1985) Failure of monoclonal antibodies to core glycolipid to bind intact smooth strains of Escherichia coli. J Infect Dis 151:1005-1011

Hastings TS, Ellis AE (1988) The humoral response of rainbow trout, Salmo gairdneri Richardson, and rabbits to Aeromonas salmonicida extracellular products. J Fish Dis 11: $147-160$

Higerd TB, Vesole DH, Goust JM (1978) Inhibitory effects of extracellular products from oral bacteria on human fibro- 
blasts and stimulated lymphocytes. Infect Immun 21: $567-574$

Jessop HL, Lambert PA (1985) Immunochemical characterization of the outer membrane complex of Serratia marcescens and idcntification of antigens accessible to antibodies on the coll surface. J Gen Microbiol 131:2343-2348

Johne B, Jarp J. Haaheim LR (1989) Staphylococcus aureus exopolysaccharide in vivo demonstration by immunomagnetic separation and electron microscopy. J Clin Microbiol 27:1631-1635

Kadurugamuwa J, Anwar H, Brown MRW, Zak O (1985) Protein antigens of encapsulated Klebsiella pneumoniae surface exposed after growth in the presence of subinhibitory concentrations of cephalosporins. Antimicrob Agents Chemother 28:195-199

King BF, Wilkinson BJ (1981) Binding of human immunoglobulin G to protein A in encapsulated Staphylococcus aureus. Infect Immun 33:666-672

Lamers CHJ, Van Muiswinkel WB (1986) Natural and acquired agglutinins to Aeromonas hydrophila in carp (Cyprinus carpio). Can J Fish Aquat Sci 43:619-624

Liang O, Ascencio F, Fransson LA, Wadstrom T (1992) Binding of heparin sulfate to Staphylococcus aureus. Infect Immun 60:899-906

Luderizt O, Staub AM, Westphal O (1966) Immunochemistry of $\mathrm{O}$ and $\mathrm{R}$ antigens of Salmonella and related Enterobacteriaceae. Bacteriol Rev 30:193-255

Mack D, Siemssen N, Laufs R (1992) Parallel induction by glucose of adherence and a polysaccharide antigen specific for plastic-adherent Staphylococcus epidermidis: evidence for function relation to intercellular adhesion. Infect Immun 60:2048-2057

McCarthy DH, Croy TR, Amend DF (1984) Immunization of rainbow trout Salmo gairdneri Richardson against bacterial kidney disease: preliminary efficacy evaluation $J$ Fish Dis 7:65-71

Mitchum DL, Sherman LE (1981) Transmission of bacterial kidney disease from wild to stocked hatchery trout. Can $\mathrm{J}$ Fish Aquat Sci 38:547-551

Munoz C, Nieto A, Gaya A, Martinez J, Vives J (1986) New experimental criteria for optimization of solid-phase antigen concentration and stability in ELISA. J Immunol Methods $94: 137-144$

Mutharia LM. Hancock REW (1983) Surface localization of Pseudomonas aeruginosa outer membrane porin protein $F$ by using monoclonal antibodies. Infect Immun 42: $1027-1033$

Nelson D, Bathgate AJ, Poxton IR (1991) Monoclonal antibodies as probes for detecting lipopolysaccharide expression on Escherichia coli from different growth conditions. J Gen Microbiol 137:2741-2751

Nelson D. Neill W, Poxton IR (1990) A comparison of immunoblotting, flow cytometry and ELISA to monitor the binding of anti-lipopolysaccharide monoclonal antibodies. $\mathrm{J}$ Immunol Methods 133:227-233

Orskov I, Orskov F, Jann B, Jann K (1963) Acidic polysaccharide antigens of a new type from $E$. coli capsules. Nature 200:144-146

Pascho RJ, Elliott DG, Streufert JM (1991) Brood stock segregation of spring chinook salmon Oncorhynchus tshawytscha by use of the enzyme-linked immunosorbent assay (ELISA) and the fluorescent antibody technique (FAT)

Responsible Subject Editor: T. Evelyn, Nanaimo, British Columbia, Canada affects the prevalence and levels of Renubacterium salmoninarum infection in progeny. Dis Aquat Org 12 $25-40$

Paterson WD, Desautels D, Weber JM (1981) The immune response of Atlantic salmon, Salmo salar L., to the causative agent of bacterial kidney disease, Renibacterium salmoninarum. J Fish Dis 4:99-111

Pollack M, Chia JSK, Koles NL, Muller M, Guelde G (1989) Specificity and cross-reactivity of monoclonal antubodies reactive with the core and lipid A regions of bacterial lipopolysacchande. J Infect Dis 159:168-188

Rockey DD, Turaga PSD, Wiens GD, Cook BA, Kaattari SL (1991) Serine protease of Renibacterium salmoninarum digests a major autologous extracellular and cell-surface protein. Can J Microbiol 37:758-763

Russo C, Callegaro I, Lanza B, Ferrone S (1983) Purification of IgG monoclonal antibody by caprylic acid precipitation J Immunol Methods 65:269-271

Sakai M, Atsuta S, Kobayashi M (1989) Attempted vaccination of rainbow trout (Oncorhynchus mykiss) against bacterial kidney disease. Bull Jap Soc Scient Fish 55 $2105-2109$

Shieh HS (1989) Protection of Atlantic salmon against bacterial kidney disease with Renibacterium salmoninarum extracellular toxin. Microbios Lett 41:69-71

Stirm S, Bessler W, Fehmel F, Freund-Molbert E (1971) Bacteriophage particles with endoglycosidase activity. J Virol $8: 343-346$

Tsuchido T, Katsui N, Takeuchi A, Takano M. Shibasaki 1 (1985) Destruction of the outer membrane permeability barrier of Escherichia coli by heat treatment. Appl Environ Microbiol 50:298-303

Turaga PSD, Wiens GD, Kaattari SL (1987a) Analysis of Renibacterium salmoninarum antigen production in situ. Fish Pathol 22:209-214

Turaga PSD, Wiens GD, Kaattari SL (1987b) Bacterial kidney disease: the potential role of soluble protein antigen(s) J Fish Biol 31(Suppl A):191-194

Weber JM, Zwicker BM (1979) Aeromonas salmonicida in Atlantic salmon (Salmo salar): occurrence of specific agglutinins to three bacterial pathogens. J Fish Res Bd Can 36:1102-1107

Wethered DB, Markey MA, Hay R.J, Mahgoub ES, Gumaa SA (1988) Humoral immune responses to mycetoma organisms: characterization of specific antibodies by use of enzyme-linked immunoabsorbant-assay and immunoblotting. Trans R Soc Trop Med Hyg 82:918-923

Wiens GD, Kaattari SL (1989) Monoclonal antibody analysis of common surface proteins of Renibacterium salmoninarum. Fish Pathol 24:1-7

Wiens GD, Kaattari SL (1991) Monoclonal antibody characterization of a leukoagglutinin produced by Renibacterium salmoninarum. Infect Immun 59.631-637

Williams P, Lambert PA, Haigh CG, Brown MRW (1986) The influence of the $O$ and $K$ antigens in determining the resistance of Klebsiella aerogenes on surface hydrophobicity and susceptibility to phagocytosis and antimicrobial agents. J Med Microbiol 21:125-132

Young CL, Chapman GB (1978) Ultrastructural aspects of the causative agent and renai histopathology of bacterial kidney disease in brook trout (Salvelinus fontinalis). J Fish Res Bd Can 35:1234-1248

Manuscript first received: April 6, 1995

Revised version accepted: November 3, 1995 